\title{
CLOCK Gene
}

National Cancer Institute

\section{Source}

National Cancer Institute. CLOCK Gene. NCI Thesaurus. Code C119689.

This gene plays a role in the expression of genes involved in circadian rhythm. 